(REVIEW ARTICLE)

\title{
Diversity and distribution of medicinal plants in the republic of South Sudan
}

\author{
Joseph Daniel Wani Lako ${ }^{1}$, Kenneth Lado Lino Sube ${ }^{1,}{ }^{*}$, Clara Stephen Guya Lumori ${ }^{1}$, Jada Pasquale \\ Yengkopiong 2, James Augustino Majok Utong 2, Sampson Akoi Binyason 2, Yatta Samuel Lukou Ngerja ${ }^{1}$, \\ Massimo Kalisto Moilinga ${ }^{1}$, Thomas Francis Lado ${ }^{1}$ and Awad Hussein Kheiralla ${ }^{1}$
}

\author{
1 University of Juba, South Sudan. \\ ${ }^{2}$ John Garang Memorial University of Science and Technology, South Sudan.
}

Publication history: Received on 20 June 2020; revised on 05 July 2020; accepted on 07 July 2020

Article DOI: https://doi.org/10.30574/wjarr.2020.7.1.0165

\begin{abstract}
This review paper focuses on knowledge, skill, practices, benefits, and experiences pertaining to use of plants as medicinal aids to help, prevent or treat physical and mental illnesses in human in African continent especially South Sudan. Attitudes towards traditional medicine vary strongly with the tradition and cultures of the people and this has raised a serious confusion between herbal medicine and witchcraft. Millions of Africans and South Sudanese in particular prefer treatment and use of medicinal plant products made from indigenous plants, because it represents an important source of affordable medicine as well as sources of income for rural communities. $25 \%$ of the world medicinal plants are found in the African continent, but only 8\% are used because information is transferred verbally from generation to generation and much is not unknown. The set back is due to lack of proof that medicinal plants are useful, safe and effective and can be used as alternative medicine. Many plants species are likely to become extinct as well as endangered as population increases demand also increases, giving greater pressure on medicinal plants. As a result, $50 \%$ of medicinal plants worldwide are threatened with extinction due to rampant exploration. Traditional herbal medicines are identified and produced by traditional medicinal practitioners in Africa. Many herbs grown in South Sudan and in African continent have valuable medical properties but traditional methods used have many disadvantages that can be corrected and developed to make them effective, stable and reproductive through the methods of scientific research.
\end{abstract}

Keywords: Medicinal plants; Alternate Medicine; African Continent; South Sudan

\section{Introduction}

The traditional knowledge related to the health of humans and animals exists worldwide [1]. Traditional medicine is the total sum of knowledge, skills, and practices based on the theories, beliefs, and experiences indigenous to different cultures that are used to maintain health, as well as preventing, diagnosing, improving, or treating physical and mental illnesses [2]. Plants have been used as medicines throughout history [3]. Indeed, medicinal plants (MCP), unlike pharmacological drugs, have several chemical working mechanism that together catalytically and synergistically produce a combined effect which surpasses the total activity of the individual constituents [4]. Over 50\% of used MCP on earth is threatened with extinction. These make them one of the most threatened group of species whose extinction will create serious consequences for local ecosystems worldwide [5]. The importance of traditional medicine as a source of primary healthcare was first recognized by the world health organization (WHO) in the primary Health Declaration of Alma Ata (1978). In Africa, attitude towards traditional medicines has a very high variability. This is mostly due to confusion between modern medicine, herbal medicine and witchcraft. Millions of Africans prefer traditional methods of treatment, and many of them use MCP products on a daily basis to treat illness [6].

\footnotetext{
* Corresponding author: Kenneth Lado Lino Sube
} 
The African continent contains $25 \%$ of the world's plant species, but fewer than $8 \%$ of MCP are commercially utilized (WHO) [7]. This is mostly because information on traditional use of MCP is transferred verbally from one generation to another without documentation [2]. The extensive use of traditional medicine in Africa, composed mainly of MCP, has been argued to be linked to cultural and economic reasons. This is why the WHO encourages African member states to promote and integrate traditional medical practices in their health system[2]. Worldwide, particularly in Africa, traditional healing plants and remedies made from indigenous plants play an important role in the health of many millions of people. Hence MCP represents an important opportunity for rural communities in the African continent as a source of affordable medicine as well as income. As a result of this, many plant species have become extinct while others endangered [8]. As Africa's population grows, demand for traditional medicine will increase and pressure on MCP resources will become greater than ever [9]. The main setback facing the use of traditional medicine is the proof required for the usefulness, safety and effectiveness of the active components in MCP [10] in order to assure the public regarding the use of MCP as alternate drugs. Traditional herbal medicines are products that have been produced by the traditional medicinal practitioners who were capable of identifying the correct plant species [11], their quality varies widely and maybe useful. Commonly, many herbal plants grown in Africa have valuable medicinal properties[12], but the traditional methods used to utilize them have many disadvantages that can be corrected and developed to select the suitable methods to make them more effective, stable, and reproducible[1].

\section{Geographical Description}

South Sudan is considered to constitute a wide variation of climatic regions extending from semi savannah to the tropical and sub-tropical region. There is a large variation in annual rainfall, from less than $300 \mathrm{~mm}$ to $1500 \mathrm{~mm}$ in the woodland savannah and to over $1500 \mathrm{~mm}$ in the tropical vegetation. South Sudan has a range of tropical continental climates with large daily and seasonal fluctuations in temperature. In the savannah, during the rainy season minimum temperatures as low as $15^{\circ} \mathrm{C}$ are common at night, while in summer maximum temperatures often exceed $44^{\circ} \mathrm{C}$. This variation in the climate has a major impact on the enormous diversity and variation in the vegetation of this country. Moreover, the character of the vegetation in the South Sudan depends largely on rainfall and soil type.

\section{Diversity and Distribution of Traditional Medicinal Plants in South Sudan.}

Most of the medicinal plants are commonly grown and farmed in South Sudan. Several researchers reported that some of these plants are native from Asia [13,14], where it is commonly cultivated, and must have been used at an early date to Africa[2]. Though they are cultivated in Africa, the species are almost tropical now, and widely planted as medicinal plants which soon tend to establish as an indigenous species. It has been widely distributed in the tropics and subtropics [15]. The species that occur in the tropical forest of South Sudan are similar to those of the drier parts of the forests of the other parts of Africa. The most common species are Accacia nilotica and Balanitesa egyptiaca, with Kigelia africana in subtropical forest (Table 1). A number of valuable timber trees also are found, including Khaya grandifoliola, Gardenia lutea, Tamarindusindica and others [16]. These species are indigenous to some other parts of Africa; however, are now widely distributed and have become naturalized in tropical region of South Sudan. Several MCP including Acacia nilotica (Sunt), Aristolochia bracteolate (Dekerytimylo), Azadirachta indica (Neem), Balanites aegyptiaca (Laloub), Calotroppisprocera (Usahr), Kigelia africana(Ungoli), Jatropha curcas (Khirwa), Tamarindus indica (Aradib), Khaya senegalensis (Kir), and Hisbuscussurratensis. Evidence-Based Complementary and Alternative Medicine of special interest for people of South Sudan were chosen for more detailed reviews based on the following criteria: MCP that form part of South Sudan herbal medicine with commercial importance in our rural and urban communities.

\subsection{Aristolochia bracteolate (Dekerytimylo)}

Aristolochia is a large plant genus with over 500 species. Aristolochia is a genus of evergreen and herbaceous perennials. Its members are commonly known as Dekerytimylo in South Sudan and are widespread and occur in the most diverse climates. Some species, like A. utriformis and A. westlandii are threatened with extinction. Aristolochia scientific name was developed from ancient Greek aristo "Best" + locheia "Childbirth" or Childbed, relating to its known ancient use in childbirth [17]. The species Aristolochia was highly regarded as a MCP since the ancient Egyptians, Greek and Romans and until the modern era; it also play a key role in traditional Chinese medicine. The plant was useful in childbirth, a preparation and plant extract was provided to women upon delivery to expel the placenta, as noted by the traditional herbalist in the first century[18].Despite its presence in ancient medicine, Aristolochia is known to contain the lethal toxin aristolochic acid[18,19]. Regardless of the toxic properties of Aristolochic acid, the decoction of Aristolochia stimulates the production and increases the activity of white blood cells, or that pipe vines contain a disinfectant which assist in wound healing, also Aristolochia bracteolata is colloquially known as "worm killer" due to hypothetical antiheminthic activity[20]. In traditional South Sudanese medicine Aristolochia species are used for acute abdominal pains, body ache and malaria. Aristolochia taxa has also been used as reptile repellents in many of the African countries 
Joseph et al. / World Journal of Advanced Research and Reviews, 2020, 07(01), 018-031

such as South Sudan. This is because, the roots used to treat snake-bites, is so offensive to these reptiles to an extend of avoiding the places where it grows as well as fleeing from the traveler who carries a piece of it in his/her hands[20,21].

\subsection{Calotropis procera (Usahr)}

Calotropis procera is originated and widespread in tropical and subtropical Africa, including the Indian Ocean islands and sub-Sahara Africa. It is commonly distributed throughout the drier parts of West and East Africa [22], including South Sudan, Kenya, Somalia, Mali and Nigeria. It is occasionally planted outside its natural distribution area; e.g. in subtropical America and Australia where it was introduced possibly as an ornamental. In many countries, particular sub-Sahara Africa Calotropis procera is only used on a local scale for medicinal purposes [23,24]. In South Sudan it is wildly distributed on a small scale. It has been cultivated in South America and the Caribbean Islands for the production of fibers. In South Sudan, there is no statistics available on production or traded volumes or value. Calotropis procera is common in semi-arid conditions on deep, sandy soils, sand dunes, roadsides, rubbish heaps, and waste places [25]. It is generally regarded as an indicator of overgrazed land and exhausted soil. It grows mostly in dry habitats with mean annual rainfall of $300-400 \mathrm{~mm}$, but also occurs in areas with up to $1000 \mathrm{~mm}$ /year. Calotropis procera is droughtresistant and highly salt-tolerant [26]. Calotropis procera is a very important plant in traditional medicine in most African countries. Many of the traditional uses of the plant have been validated by research, and much pharmacological research has been effected including its anticancer[27], anti-ulcer, anti-inflammatory, anti-diarrheal, antioxidant[28], wound-healing, and cough-suppressing[29], smooth muscle-contracting and neuromuscular blocking activity as well as larvicidal, antihelmintic, antiviral, antibacterial and antifungal activities in vitro and in vivo[30,31]. However, in South Sudan Calotropis procera will remain a major MCP and become more important particularly with the new born children as it used by rubbing it on the remaining umbilical cord in order to accelerate its healing. The industrial demand for Calotropis procera is likely to increase as novel MCP if developed.

\subsection{Balanites aegyptiaca (Lugwat)}

Balanites aegyptiaca is a species of tree classified either as a member of the zygophyllaceae or the balanitaceae [32, 33]. This tree is native to much of African countries such as South Sudan, Somalia and Kenya, and part of the Middle East $[34,35]$. There are many common names for this plant. In English the fruit has been called desert date, throne tree, Egyptian myrobalan, Egyptian balsam or Zachum oil tree [36]. In South Sudan and some Arabs countries such Sudan it is known as Laloub. In Hausa it is called Aduwa, in Swahilli it is known as Mchunju and in Amharic is called Bedena[36,37]. Balanites aegyptiaca is found in the Sahel Savannah region across Africa. It is one of the most common trees in South Sudan, Sudan, Senegal and Mauritania. It can be found in many kinds of habitats, tolerating a wide variety of soil types from sand to heavy clay, and climatic moisture levels from arid to sub-humid. It is relatively tolerant to flooding, live stock activity, and wildfire [38].Balanites aegyptiaca has been cultivated in Egypt for more than 4000 years. The tree was figured and described in 1592 by prosper Alipinus under the name agihalid. The genus Balanites was found in 1813 by Delile [3,36]. The yellow single seeded fruit is edible, but bitter in taste [32]. Many parts of the plant are used as famine food in many African countries; the leaves are eaten raw or cooked, the oily seed is boiled to make it less bitter and eaten mixed with sorghum to prepare porridge [36]. The Balanites tree is considered valuable in arid regions because it produce fruit even in dry seasons [40, 41].The seeds of the Balanites aegyptiaca have molluscicide effect on Biomphalaria pfferi [42]. Desert date fruit is mixed into porridge and eaten by nursing mothers, and the oil is consumed for headache, stomachache and to improve lactation [32]. Bark extracts and the fruit act as repellent or destroyer of freshwater snails and copepods, organisms that act as intermediary hosts of the parasites, Schistosoma and Guinea worm, respectively. Existing worm infectious are likewise treated with desert date as well as liver and spleen disorders [42]. The seed contains 30-45 \% fixed (non-volatile) oil. Like the leaves, fruit pulp, bark and roots, contains the sapogenindiosgenin and yamogenin [43]. Saponins similarly occur in the root, bark wood and fruit [44]. Diosgenin can be used to produce hormones such as those in combined oral contraceptive pills and corticoids [45].

\subsection{Kigelia africana (Ungoli)}

Kigelia africana is an African tree, easily recognized due to the large sausage shaped fruits hanging from its branches. Sausage trees are sacred to many communities in the African continent particularly in South Sudan, and are often protected when other forest trees are cut down. In South Sudan, the Bari people and similarly Luo and Luhya people from Kenya bury a fruit to symbolize the body of a lost person believed to be dead. Every part of the tree is used in herbal medicines (e.g., for digestive and respiratory disorders and to treat infections and wounds)[22]. The sausage tree is used in a variety of commercial applications to treat skin infections. Research into its antibacterial, antifungal and antitumor activity was carried [46]. The Sausage tree is found across sub-Sahara tropical Africa and as far south as South Africa. It is cultivated in other tropical countries and is used as an ornamental tree in Australia, the United State of America and parts of South East Asia [47]. Kigelia africana is an important tree for many people and has a wide range 
of uses. Both ripe and unripe fruits are poisonous to humans but the fruits can be dried and fragmented, and used a long with the bark to enhance the flavor of traditional beers in some parts of South Sudan. The seeds are sometimes roasted and eaten in times of food shortage. The wood makes good quality timber for fences, planking, boxes and canoes. The traditional African healers use Kigelia africana to treat a wide range of skin ailments from fungal infections, boils, acne, and psoriasis [48], through to more serious diseases, such as leprosy, syphilis and skin cancer. It is also used effectively to dress wounds and sores. The Tonga women of the Zambezi valley apply cosmetic preparation of Kigelia to their faces to ensure a blemish free complexion. Yong men and women also used it to enhance the growth of their genitalia and breast respectively. Kigelia africana is also taken orally to treat conditions such as dysentery, ring worm, malaria, diabetes, pneumonia, viral and bacterial infection [49].

\subsection{Tamarindus indica (Kite)}

Tamarindus indica is indigenous plant commonly found in tropical and sub-tropical belt; it is widely distributed throughout Africa to South Asia, Northern Australia and Oceania [50,51]. The plant is grown wildly in Africa in locations as diverse as South Sudan, Sudan, Kenya, Nigeria, Cameroon, Senegal, and Tanzania, but has been cultivated for so long on the Indian sub-continent [52]. However, it has been reported to be indigenous in that part of the world with warm climate [53]. In Arab world, it is found growing wildly in Oman. Today, India is the largest producer of Tamarind. The consumption of Tamarind is widespread due to its central role in the cuisines of the Indian sub-continent [54]. Apart from its fruit being used as a source of food, it is one of the best ornamental trees of the tropics. The fruit became known in Europe in the middle ages, when grown in deep rich soils, attaining a height of 80 feet [55]. Tamarindus indica is a plant commonly used as a source of food in many African countries and Indian sub-continent; it has potential to improve nutrition, boost food security, and foster rural development and support sustainable development. Tamarindus indica has been used for many years as MCP throughout Africa and South-East Asia with fruit used as a poultice applied to foreheads of fever sufferers [56]. Tamarind intake is likely to help in delaying progression of skeletal fluorosis by enhancing urinary excretion of fluoride [57].

\subsection{Jatropha curcas (Khirwa)}

Jatropha curcas is a species of flowering plant in the family of Euphorbiaceae. It is originated from American tropical region, most commonly Mexico and other countries in Central America [58, 59].The plant is commonly known as Khirwa by the South Sudanese. Jatropha curcas is widely cultivated in both tropical and sub-tropical regions around the world $[59,60]$. The seed is containing up to $40 \%$ oil which involved in production of high quality biodiesel [61]. Furthermore Jatropha curcas is multipurpose plant which has many other uses and benefits in health and environmental [62]. Jatropha curcas has been reported to have many of health benefits because of its wide range of medicinal uses [63]. The medicinal uses of this species range from external to internal [59]. The different parts of this plant including the leaves, fruits and barks contain many compounds such as glycosides, flavonoids, which exhibits wide range of medicinal properties [64, 65, and 66]. Jatropha curcas leaves are regarded as antiparasitic and also applied to hard tumor [67, 68]. In South Sudan, people from rural areas use the Jatropha curcas juice from their leaves to treat bee or wasp sting. The leaves, when pounded can be applied on the eye of a horse to scare flies and it's also reported that it can be used against muscular pains $[69,70]$. The oil from Jatropha curcas seeds is used on skin for treating rashes and skin parasitic diseases [71]. Jatropha curcas has also internal medicinal uses: The stems of young leaves have been used to treat urinary infections. The tender twig is used as a tooth brush to clean and protect the teeth [72]. The juice from the leaves can be used to relieve pains from the sore tooth [73]. The other use of Jatropha curcasits fruits and seeds among people in rural areas in South Sudan is believed to be as a contraceptive for birth control. The plant is usually used in many African countries as a natural pesticide because of its toxicity [61].

\subsection{Hisbiscus surratensis (Karkedeh)}

Hibiscus is a quite large family, containing several hundred species that are native to warm temperate, tropical and subtropical regions throughout the world particularly Africa and Indian sub-continent. The major producing countries are Jamaica and Mexico. The tea made out of Hibiscus flowers is known by many names in many countries around the world and is served both hot and cold [74]. The beverage is well known for its color, and flavor. In South Sudan, Sudan, Egypt and the Arab world, Hibiscus tea is known as Karkedeh. Hibiscus leave is edible as a vegetable, the species are very good ingredient in cooking native dishes, the leaves have been used like spinach $[74,75]$. In many areas in South Sudan this plant has been used to treat many health problems such as cold, lowering blood pressure and constipation. The plant used widely in Egypt for the treatment of cardiac and Nerve diseases, and has been described as a diuretic. Hibiscus has been used in the treatment of cancer [76]. In many countries like Iran, drinking sour tea from Hibiscus is a popular practice for treatment of hypertension [77]. Hibiscus is regarded as a tonic for heart and stomach. Hibiscus is also been used externally: The ash from the plant is applied to cuts and an infusion is used to treat itch caused by Chickenpox in rural communities in South Sudan. The leaves are used in poultices to treat conditions such as boils; the dried leaf 
powder is used to cure wounds. The seed has been used as a remedy for eye diseases and dysentery. Hibiscus root decoction is used as a laxative.

\subsection{Khaya senegalensis (Kiyir)}

Khaya senegalensis is a deciduous evergreen tree, $15-30 \mathrm{~m}$ high, and up to $1 \mathrm{~m}$ in diameter. Khaya senegalensis is insect pollinated, flowering shortly before or early in the rainy season, the fruit apparently remaining on the tree throughout the dry season [78, 79]. When the fruit ripens; the colour changes from grey to black. Khaya senegalensis occurs in riverine forests and scattered within the higher rainfall savannah woodlands. In moisture areas, Khaya senegalensis is found on uplands, but it is restricted to riparian habitats or stream bottoms that extend into the savannah in the drier portions of the region $[16,80]$. It is also very resistant to flooding and can be considered for planting in swampy soils, moderately shade tolerant [81]. Khaya senegalensis has a very bitter bark and has a considerable reputation in its natural range as a fever remedy; the bark is also used as a vermifuge and for treating syphilis. The bark extract is used in South Sudan and many other African countries for treating jaundice, dermatoses, scorpion bite, and allergies infection of gum, hookworm, bleeding wounds (disinfectant) and as a laxative. Khaya senegalensis seeds and leaves are used for treating fever, headache; roots are used against sterility, for the treatment of mental illness, syphilis, and leprosy. Bark also used in traditional veterinary practice. For instance cattle suffering from liver fluke, for ulcer in camels, donkeys and horses, and in horses for internal ailments associated with mucous diarrhea [82].

\subsection{Azadirachta indica (Neem)}

Azadirachta indica, the exact originate of this plant is not known but it is thought to be native of the Indian sub-continent (India and Bangladesh) and South-East Asia. Azadirachta indica is naturalized in many locations include; Northern Australia, Tropical Asia, Africa, Fiji, the Caribbean and many countries in South and Central America[11] . Azadirachta indica has rapidly spread in parts of many African countries including South Sudan, Sudan, Kenya, Uganda and Tanzania. In the coastal countries such as Tanzania and other Indian Ocean States it is known as "The Panacea" in Kiswahili (the tree that cure forty diseases)[83]. Azadirachta indica is considered to be very effective in the treatment of many diseases such as Scabies as well as being used as an insecticide. The wood is hard and resistant to termites, borers and fungi. Azadirachta indica has been shown to be an important agent in treating infestations of head lice in human particular in South Sudan. Its oil is also used in sprays against fleas for cats and dogs as well as in some beauty products [84]. However, prolonged internal use may cause irritation of liver and kidneys for its poisonous is effective when taken at higher concentrated doses. Azadirachta indica products have been used in India for over two millennia for their medicinal properties [85]. These products, according to Siddha and Ayurvedic practitioners, are believed to be antihelmenthic, antifungal, antidiabetic, antibacterial, antiviral, and contraceptive [86]. Azadirachta indica is considered as a major component in Siddha medicine and is particular prescribed for skin diseases [85, 87]. In adults, short term use of Azadirachta indica is safe, while long term use may harm the kidneys or liver in children. Azadirachta indica oil is toxic and can lead to death, may also cause miscarriages, infertility, and low blood sugar [88].

\subsection{Acacia nilotica (Sunt)}

Acacia nilotica, commonly known as Gum Arabic tree, has been recognized worldwide as a multipurpose tree [89]. It is widely distributed throughout tropical and sub-tropical regions of the world particular in Africa. It is commonly cultivated within $30^{\circ} \mathrm{N}$ and $20^{\circ} \mathrm{S}$ [25,90 and 91]. It is a relatively fast growing, drought resistant multipurpose legume with the ability of biological nitrogen fixation [92]. Acacia nilotica grows best on cracking clay soils that have high water holding capacity, but can also grow on sandy soil in areas of higher rainfall. The herb Acacia nilotica belongs to the order Fabales and the family Fabaceae, the tree Acacia nilotica originated from Africa (Sudan, Somalia and South Sudan), but also occurs as a wild plant in the Arabian peninsula and Indian sub-continent. The herb Acacia nilotica has found many uses as MCP in South Sudan. Acacia nilotica is widely used in traditional medicine [25]; it can be consumed internally in regular doses for a short period of time to provide relief in the case of diarrhea. It is extremely effective in keeping the gums and the teeth healthy. The bark of the Acacia nilotica tree can be chewed; this practice not only strengthens the teeth but also cleans them [93]. Externally, Acacia nilotica can be prepared using its gum mixed with the pulp of mango to be applied on skin in case of eczema. The Acacia nilotica leaves, when boiled with water according to our traditional healers leave a residue in it. This water should be applied regularly over the eyes to relieve Epiphora disorder [91].

\section{Traditional medicinal Plants and Healthcare}

In South Sudan the effect of several MCP used were tested, evaluated and identified for activity against various diseases [94]. The effective MCP that were tested were selected on the basis of information which was obtained from the traditional medicinal practitioners on their curative effect in the treatment of many diseases such as malaria, typhoid, diarrhea, antibacterial, antifungal, inflammations, asthma, sleeping sickness, jaundice etc [15]. 
Table 1 Some traditional plants of South Sudan

\begin{tabular}{|c|c|c|c|c|c|}
\hline S/No & Plants species & Local name & Family & Part used & uses \\
\hline 1 & Aloe vera & Sabbar & Agavaceae & $\begin{array}{l}\text { Flowers, } \\
\text { leaves }\end{array}$ & Dermatitis, \\
\hline 2 & Sclerocarya birrea & & Anacardiaceae & Leaves & Glycaemia control \\
\hline 3 & Aristolochia bracteolate & Dekery-timylo & Aristolochiaceae & Leaves, roots & Malaria, fever \\
\hline 4 & Calotroppis procera & Uhsahr & Asclepiadaceae & $\begin{array}{l}\text { Milky juice, } \\
\text { flowers }\end{array}$ & Cholera, asthma, wounds \\
\hline 5 & Vernonia kotschyana & & Asteraceae & Leaves & Gastric ulcers \\
\hline 6 & Balanites aegyptiaca & Laloub & Balanitaceae & $\begin{array}{l}\text { Fruits kernel, } \\
\text { leaves }\end{array}$ & $\begin{array}{l}\text { Lowering blood pressure, } \\
\text { stomach disorders }\end{array}$ \\
\hline 7 & Kigelia africana & Ungoli & Bignoniaceae & Fruits & Syphilis, antibacterial \\
\hline 8 & Senna alata & & Caesalpiniaceae & Leaves & Mycosis, antiviral \\
\hline 9 & Terminalia brownii & & Combertaceae & Wood, roots & Hepatitis \\
\hline 10 & Tamarindus indica & Aradib & Combertaceae & Fruits & Laxative, pneumonia \\
\hline 11 & Ricinus cummunis & Castor oil & Euphorbiaceae & Leaves & Fever \\
\hline 12 & Euphorbia hirta & & Euphorbiaceae & Entire plant & $\begin{array}{l}\text { Anti-asthmatic, antidysenteric, } \\
\text { antifungal, diuretic }\end{array}$ \\
\hline 13 & Jatropha curcas & Khirwa & Euphorbiaceae & Leaves, seeds & $\begin{array}{l}\text { burns, retained placenta, } \\
\text { dermatitis, biofuel }\end{array}$ \\
\hline 14 & Plectranthus amboinicus & No local name & Lamiaceae & Leaves & Wounds and injuries \\
\hline 15 & Hisbiscus surratensis & Karkedeh & Malvaceae & Leaves, fruit & $\begin{array}{l}\text { Laxative, cancer, lowering blood } \\
\text { pressure, cold } \\
\text { and flu }\end{array}$ \\
\hline 16 & Khaya senegalensis & Kir/Mahogany & Meliaceae & Leaves, roots & Diarrhea, stomach, worms \\
\hline 17 & Azadirachta indica & Neem & Meliaceae & Fruits, leaves & Malaria, insecticides \\
\hline 18 & Accacia nilotica & Sunt & Mimosaceae & Fruit & Antiseptic \\
\hline 19 & Moringa oleifera & & Moringaceae & Leaves & Dietary supplement, dysenteria \\
\hline 20 & Eucalyptus citriodora & Rihan & Myrataceae & Leaves & Insect repellent \\
\hline 21 & Eucalyptus globulus & Kafoor & Myrataceae & Leaves, bark & Respiratory disease \\
\hline 22 & Psidium goyava & Guyava & Myrataceae & Leaves, fruit & Diarrhea \\
\hline 23 & Dalbergia melanoxylon & Abunos & Papilionaceae & Leaves, bark & Parasitic worms \\
\hline 24 & Ziziphus mauritiana & & Rhamnaceae & Leaves, fruit & Cut, wounds, ulcers \\
\hline 25 & Crossopterix febrifuga & & Rubiaceae & $\begin{array}{l}\text { Leaves, fruits, } \\
\text { roots }\end{array}$ & Gonorrhea, fever, cough, worms \\
\hline 25 & Gardenia lutea & Abu gowi & Rubiaceae & Fruits & Constipation \\
\hline 27 & Datura metel & Mekerere & Solanceae & Seeds & Narcotic \\
\hline
\end{tabular}

\section{Medicinal plants conservation}

Conservation plants remain the main area of agricultural experts. It provide an important insurance against the loss of plants genetic material and resources with a major role to play in terms of preservation and species reintroduction projects, such as education and research[95]. The conservation of traditional medicinal plants resources can be achieved through different methods such as seed preservation and forest protection as well as maintenance of living collection [96]. In many ways the protection of the plants in the forest sometimes may not be possible because of human activities in the rural areas such as cutting trees for fuel wood and building materials [97]. In many African countries the widespread practice used by most of people particularly in Sub-Sahara Africa is conserving edible wild fruit bearing trees for their fruits and shade; also ensures availability of some traditional medicines with multiple use 
species $[98,99]$. Similarly, like in other African countries, South Sudan people are protecting the vegetation at grave sites, for religious and spiritual reasons, an important means through which biotic diversity is maintained outside center of conservation areas [100]. Religious beliefs among South Sudanese have also help to ensure careful harvesting of certain type of species such as Eucalyptus citriodora

\section{Utilization of Medicinal Plants for healing in South Sudan}

Medicinal plants have been used by mankind for centuries; their use is as old as humanity itself. The range of medicinal plant species used and their capacity for healing are enormous. In Sub-Sahara Africa including South Sudan the ratio of traditional medicinal practitioners to the population is around 1:500, whereas medical doctors have a 1:40,000 to the rest of the total population [101]. Based on research studies, the total amount of pharmaceutical drug supply available globally only $35 \%$ is consumed in developing countries and more than $60 \%$ of people rely on traditional medicine for their primary healthcare [102]. Currently, the number of higher plant species used worldwide for medicinal purposes is estimated around 50,000 species [103]. This is representing the biggest spectrum of biodiversity used by people for a healing purpose [104].

Traditional medicine is accumulative of the knowledge skills and practices based on the theories, beliefs and experiences belonging to indigenous different cultures usually used in the maintenance of health of rural and urban populations as well as prevention, diagnosis improvement or treatment of physical and mental illness [102]. Currently majority of South Sudanese are involved in traditional therapy using medicinal plants. This is because they are easily accessible and cheaper. Furthermore western medicines most of the times need consultation with medical personnel. This increase the cost which is made worsens with the rocking prices of western drugs. Strong cultural preference for traditional medicine has made MCP as fundamental medications for well-being of many people in the country. However, traditional remedies are not limited to African people but they are more demanded in developed countries such as Europe and Asia, alongside growing environmental awareness and a desire for natural healing through natural products $[7,105]$.

\section{The Role of Traditional Medical Practitioners}

In many African countries including Tanzania the number of the traditional practitioners was estimated to be 30,000 40,000 in comparison with 600 doctors [106]. Similarly, in Malawi, there was an estimated 17,000 traditional medical practitioners and only 35 medical doctors in the country[107].In South Sudan the number of traditional practitioners is not known but they is increment in local, regional and international practitioners from the neighboring countries as there is increase in demand of their services. This is more justifiable by seeing a lot of the leaflets and posters advertising foreign traditional practitioners. More over media outlets play a bigger role in encouraging people to meet them in their clinics. In South Sudan the norms and use of MCP was regulated in the past by several indirect controls practice. Illegal and social restrictions on gathering MCP and the nature of plant gathering equipment all served to limit MCP harvesting in our rural areas. In other parts of the continent including Southern Africa in the past, before metal machetes and axes were widely used, plants were collected with small digging tools such as wooden digging stick or small axes. This was intended to limit the quantity of bark or roots gathered[108].Traditionally, in South Sudan, our rural communities particularly in the last century have relied upon the spiritual healers as well as traditional medicinal practitioners whose knowledge of plant species and their ecology were valuable[95]. Commonly in Africa, the gathering of MCP was traditionally restricted to traditional practitioners and their family members who are keen in following their parent's footstep. Our people in the rural areas believe that knowledge of many species of MCP is limited to the Traditional medicinal practitioners through spiritual call. Similarly to other African countries South Sudan proposed significant justification for optimism in shifting from using traditional medicines to consulting medical doctors. This transformation occurs with socio-economic, cultural changes, access to formal education and religious influences. Access to western medicine, adequate education and employment opportunities requires economic growth. Unfortunately, many African countries including South Sudan are affected by unprecedented economic deterioration, and increasing in population growth which resulted to the difficulties of adequate provision of western type of health services. Therefore, there is a need to involve traditional medicinal practitioners in national healthcare systems through training and evaluating effectiveness of the remedies $[107,109,110]$. Recently, South Sudanese traditional medicinal practitioners are playing a key role as an influential group in primary healthcare.

\section{Domestic Trade}

Medicinal plants are clearly becoming an important global resource in terms of healthcare[105] as well as an important economic resource, traded extensively ranging from the local to the international level[111]. The trade in medicinal 
plants is estimated at 60 billion dollars annually [112]. African countries particularly South Sudan have the highest rate of urbanization since its independence, with the urban population growing rapidly in the cities each year. In rural areas throughout the country, wild plant resources fulfill a wide range of basic needs and are a resource for basic harvested plants for informal trade [113]. Urbanization results in general reductions in the number of species and quantities of certain wild plant resources as population enter the cash economy, alternative foods, utensil and building materials, and alternative energy sources. However, Informal sector trade in wild plant resources continues to be very important in many cities: fuel wood is used widely in the country as an alternative energy source [114] such as electricity and gas for the reason of not being available or affordable $[115,116]$. Furthermore high urban demand for fuel wood and building materials can undermine the rural areas resource by causing the depletion of favored but slow growing species such as Tamarindus indica, and Kigelia africana. In stressed environment and financial difficulties represented by rocking prices for western medicines seen in many urban areas and cities in South Sudan, it is not surprising that demand for traditional medicinal and animal materials increases which is believed to have a symbolic or psychosomatic value $[116,117]$.

\section{The Impact of the Trade of Medicinal Plants (MCP)}

The commercial trade and gathering of traditional medicines in many countries with small urban populations such as South Sudan is limited and cases of over-exploitation are rare depending on the types of species [95]. Harvesting of MCP by local traditional practitioners in many parts of the country is an ongoing activity but selective and on a small scale. In South Sudan with high rural population densities and small cities [95], gathering of MCP is expected to be in small scale especially where a species is popular and supplies are low due to habitat destruction and agricultural expansion, the tree will suffer many cuts rather than one-off ring due to commercial harvesting [113]. It is clear that MCP species gathered for commercial purposes represent the most popular and effective herbal remedies. Majority of species that were popular in the past are still popular today [96,118]. Recently South Sudanese MCP gatherers are facing difficulties to find the plants. This may be due to limited geographical distribution of the species, habitat destruction or overexploitation. For example, in South Sudan plants such as Balanites aegyptiaca, Tamarindus indica, and Jatropha curcas, are commercially sold species thus represent a short list of the medicinal plant used nationally. Many species that are used to a limited extent in rural areas are not in demand in the urban areas.The majority of our traditional medicines have not being adequately screened for active ingredients. Efforts should be directed to promote conservation of the known species as well as supporting creation of department in agriculture for medicinal plants.

\section{Education and Training}

The conservation and preservation of MCP in Republic of South Sudan is very crucial. This process requires the development of competent and well trained staff. This will need more support from the government, interested organizations, private partners and general public. Development of national policies becomes a key factor in conservation and preservation of MCP. This will result to the improvement of the economy of the country. More over policies are needed to be designed by higher education and ministry of health to incorporate MCP into the medical curriculum as well as national health policies. There is need of development an institute for the MCP in the country in order to produce cadres who are expert in it. Furthermore the institute should have an advanced laboratory that will assist in isolation of the active ingredient of the MCP. Eventually MCP could be put into clinical trials for its efficacy, side effects and dose for better future consumption by the public. This institute should collaborate with sisterly regional and international ones for it to become a center of Excellency.

Increasing public awareness for the importance of MCP protection, conservation and consumption is a necessity. Furthermore encouragement of the community to cultivate, protect and expand MCP is highly needed in the country. For a better success, particular groups should be targeted like: Rural communities, traditional leaders, Faith base organizations government decision makers, and healthcare sector to play a greater role in promoting MCP in the nation. There is a need for the development of media programmes for easy and wider consumption of information related to MCP.

Information which identifies threatened MCP and habitat destruction should be reported and disseminated via media outlets. The government should develop strategies to ensure that the destructed MCP by human activities are replaced. Education should be used as a way of inspiring and motivating action and public support to develop the MCP sector. Moreover education about MCP may take different forms: starting from educating end consumer about the sources of their medicines to educating farmers and herbs gatherers about the values and sustainable harvest. The medicinal plant practitioners have a key role to play in educating the public about the value and conservation needs for MCP. 


\section{Research and Monitoring}

Research into the identification and conservation of MCP species of high biological diversity and properties of usage of specific plants should use the complementary skills of the Traditional practitioners and conservation biologists. This will enable monitoring of species of plants which are use as medicinal in our country. Database of the country MCP should be established to assist in utilization of them in a scientific manner. Our primary focus of research should be on heavily populated areas where plant scarcities are like to occur as a result of human activities. The initiation of a series of interactive discussions involving traditional medicinal practitioners, commercial gatherers, and market based local trades and conservation researches to discover the perceived scarcity of species, sites of diversity, and the status of popular species. Studies should be designed for selected areas or regions to assess the economic viability and social acceptability of large scale of production of MCP. Nationwide survey is needed to identify the amount and types of the MCP available in the country. This should involve those who have local knowledge about traditional medicine like: traditional healers, agriculturists, farmers, some religious leaders and others. This will speed up setting of national MCP data base. The government should appoint a focal person from relevant authority to carry damage assessment for the threatened plants species which are over-exploited by the traders of MCP. The initiation of cultivation as a conservation method should help us to preserve and monitor the areas with main species under cultivation or threaten by extinction.

\section{Future Perspective}

The use of MCP is mostly carried out by traditional healers to treat diseases. Because of this, the information in the use of traditional medicine and healing has to be documented and developed. This is a priority in the healthcare system. It is important for South Sudan to enhance the development of the methods of extraction of active components from medicinal plants to their benefits.

Furthermore, research and training activities for traditional medicine has not received any financial support. As a result, the quantity and quality of safety and efficacy data are far from sufficient to meet the demands of the used traditional medicine in the Africa continent. Commonly, funds allocated for research is indeed insignificant. Therefore, we are looking for international institutions to provide the necessary financial support to promote the potential role of the herbal medicine industry.

\section{Conclusion}

South Sudan has a rich traditional plants species, an immense range of climates, cultures and human resources that can make her to become a leading producer of natural plant products in the region as well as in Africa. The pharmaceutical potentials of South Sudan in MCP are enormous. Urgent action is needed for research that focuses on the generation of basic information on MCP and for promoting value-added processing of herbal medicines from local materials for local markets with simple quantity forms being standardized and package at low cost using appropriate methods. This will require the purchase of some equipment so that primary investigations can be carried out on sight which can then be followed by elaborate characterization of the species of interest in some advanced laboratories.

\section{Compliance with ethical standards}

\section{Acknowledgments}

The authors would like to acknowledge the hard work of the herbal plant society for providing us with some of the local available names of the plants and their uses. We are thankful to the departments of Agriculture and Forestry in the state and National ministries for their encouragement and technical support. Furthermore, we appreciate the efforts of the department of wildlife, College of Natural Resources and Environmental studies, University of Juba for facilitating in identifying and providing their scientific names. We would like acknowledge the role played by local healers in maintaining and preserving these plants for generations and generations. If not them, we would have lost a lot of the plants. We would have failed to identify these plants.

\section{Disclosure of conflict of interest}

The authors do not disclose any conflict of interest. 


\section{References}

[1] Bodeker G. (1994). Traditional health knowledge and public policy. Nature and Resources, 30, 5-16.

[2] Mahomoodally MF. (2013). Traditional medicines in Africa: An appraisal of ten potent African medicinal plants. Evidence-Based Complementary and Alternative Medicine, 1-14.

[3] Sofowora A. (1982). Medicinal plants and traditional medicine in Africa, John Wiled and Sons Limited, Chichester.

[4] Shohawon S and Mahomoodally MF. (2013). Complementary and alternative medicine use among Mauritian women. Complementary Therapies in Clinical Practice, 19, 36-43.

[5] Brooker R. (2006). Plant-plant interaction and environmental change. New Phytologist, 171, $271-284$.

[6] Mwangi JW. (2000). Traditional herbal medicine in Kenya, University of Nairobi, Nairobi, Kenya.

[7] WHO. (1977). Final Report: Seminar on the Use of Medicinal Plants in Healthcare. Tokyo, Japan, September. Manila, Philipines. WHO Regional Office for the West Pacific (cited by Prescott-Allen, R.; Prescott Allen, C. What's wildlife worth? London, Earthscan).

[8] Kokwaro JO. (1993). Medicinal plants of East Africa, Second Edition, University of Nairobi, Kenya.

[9] Association of African Medicinal Plants Standards (AAMPS).

[10] Hostettmann K, Marston A, Ndjoko K and Wolfender J-L. (2000). The Potential of African Plants as a Source of Drugs. Current Organic Chemistry, 4, 973-1010.

[11] Gurib-Fakim A. (2006). "Medicinal plants: traditions of yesterday and drugs of tomorrow,".Molecular Aspects of Medicine, 27, 1-93.

[12] Farnsworth NR, Akerele O, Bingel AS, Soejarto DD and Guo Z. (1985). "Medicinal plants in therapy," Bulletin of the World Health Organization, 63, 965-981.

[13] Alok SK. (1991). Medicinal plants in India: approaches to exploitation and conservation. In O. Akerele; V. Heywood; H. Synge (eds), Conservation of Medicinal Plants, 295 - 304.

[14] Malla SB. (1982). Medicinal Plants of Nepal. FAO Regional Office for Asia and the Pacific. Report No. 64. Bangkok. FAO.

[15] Balick JB, Elisabetsky E and Laird AS. (1996). Medicinal resources of the tropical forest, Biodiversity and its importance to human health, Columbia University Press, New York.

[16] Vogt K. (1995). A field guide to the identification, propagation and uses of common trees and shrubs of dryland Sudan. SOS Sahel International (UK).

[17] Prachi G, Haruyo I, Nikita M, Gautam S and Bharat BA. (2007). From ancient medicine to modern medicine: ayurvedic concepts of health and their role in inflammation and cancer. Journal of Society Integrated Oncology. 5 , 25-37.

[18] Vanhaelen M, Vanhaelen-Fastre R, But P and Vanherweghem J-L. (1994). Identification of aristolochic acid in Chinese herbs. Lancet, 343, 174.

[19] Cosyns JP. (2003). Aristolochic acid and Chinese herbs nephropathy: a review of the evidence to date. Drug Safety, 26, 33-48.

[20] Heinrich M, Chan J, Wanke S, Neinhuis C and Simmonds MS. (2009). Local Uses of Aristolochia species and content of Aristolochic Acid 1 and 2 - a global assessment based on bibliographic sources. Journal of Ethnopharmacology, $125,108-144$.

[21] Freeman-Mitford AB. (1992). The Bamboo Garden (1896) quoted in Alice M. Coats, Garden Shrubs and Their Histories (1964), S.V. "Aristolochia".

[22] Burkill HM. (1985). The useful plants of West Tropical Africa. 2nd Edition. Volume 1, Families A-D. Royal Botanic Gardens, Kew, Richmond, United Kingdom, 960.

[23] Ahmed KKM, Rana AC and Dixit VK. (2005). Calotropis species (Asclepiadaceae) - A comprehensive review. Pharmacognosy Magazine, 1, 48-52.

[24] Neuwinger HD. (2000). African traditional medicine: a dictionary of plant use and applications. Medpharm Scientific, Stuttgart, Germany, 589. 
[25] Orwa C, Mutua A, Kindt R, Jamnadass R and Anthony S. (2009). Agroforestree Database: a tree reference and selection guide version 4.0. World Agroforestry Centre, Kenya.

[26] Bekele-Tesemma A. (2007). Useful trees and shrubs for Ethiopia: identification, propagation and management for 17 agroclimatic zones. Technical Manual No 6. RELMA in ICRAF Project, Nairobi, Kenya, 552.

[27] Choedon T, Mathan G, Arya S, Kumar VL and Kumar V. (2006). Anticancer and cytotoxic properties of the latex of Calotropisprocera in a transgenic mouse model of hepatocellular carcinoma. World Journal of Gastroenterology, $12,2517-2522$.

[28] Chavda R, Vadalia KR and Gokani R. (2010). Hepatoprotective and antioxidant activity of root bark of CalotropisproceraR.Br (Asclepediaceae). International Journal of Pharmacology, 6, 937-943.

[29] Bharti S, Wahane VD and Kumar VL. (2010). Protective effect of Calotropisprocera latex extracts on experimentally induced gastric ulcers in rat. Journal of Ethnopharmacology, 127, 440-444.

[30] Bagherwal P. (2011). Immunomodulatory activities of the non-dialyzable latex fraction (NDL) from Calotropisprocera(Ait.) R. Br. International Journal of Research in Pharmaceutical and Biomedical Sciences, 2, 114119.

[31] Moustafa AMY, Ahmed SH, Nabil ZI, Hussein AA and Omran MA. (2010). Extraction and phytochemical investigation of Calotropisprocera: effect of plant extracts on the activity of diverse muscles. Pharmaceutical Biology, 48, 1080-1090.

[32] Iwu MM. (1993). Handbook of African medicinal plants. Boca Raton u.a.: CRC Press, 129.

[33] Dastagir G, Hussain F and Khan AA. (2012). Antibacterial activity of some selected plants of family Zygophyllaceae and Euphorbiaceae. Journal of Medicinal Plants Research, 40, 5360-5368.

[34] Hall JB and Waljer DH. (1991). School of Agricultural and Forest Science. Banger: University of Wales;Balanitesaegyptiaca Del. A monograph, 1-12.

[35] Hall JB. (1992). Ecology of a key African multipurpose tree species Balanitesaegyptiaca Del. (Balanitaceae): The state of knowledge. Forest Ecological Management, 50, 1-30.

[36] Chothani DL and Vaghansiya HU. (2011). A review on Balanitesaegyptiaca Del (desert date) phytochemical constituents traditional uses and pharmacological activity. Pharmcognosy Review, 5, 55-62.

[37] Azene T. (2015). Balanites (Balanitesaegyptiaca) Del. Multipurpose trees a prospective review. International Journal of Modern Chemistry and Applied Science, 2, 189-194.

[38] Barley S, Watt JM and Breyer- Brandwijk MG. (1962). Zygophyllaceae. In: ed. The Medicinal and poisonous plants of Southern and Eastern Africa. Livingstone Ltd. London, 1064.

[39] Guinand Y and Lemessa D. (2000). "Wild-Food Plants in Southern Ethiopia: Reflections on the role of 'faminefoods' at a time of drought" UN-OCHA Report.

[40] Ndoye M, Diallo I and Gassama YK. (2004). Reproductive biology in Balanitesaegyptiaca (L.) Del., a semi-arid forest tree. African Journal of Biotechnology, 3, 40-46.

[41] Dubey PK, Yogi M, Bharadwaji A, Soni ML, Singh A and Sanchan AK. (2011). Balanitesaegyptiaca (L.) Del, a semiarid forest tree: A review. Academic Journal of Plant Sciences, 4, 12-18.

[42] Hamidou TH, Kabore H, Ouattara O, Ouédraogo S, Guissou IP and Sawadogo L. (2002). "Efficacy of Balanitesaegyptiaca (L.) DEL Balanitaceae as Anthelminthic and Molluscicide Used by Traditional Healers in Burkina Faso". International Conference on Emerging Infectious Diseases, 37.

[43] Chapagain BP, Saharan V and Wiesman Z. (2008). Larvicidal activity of saponins from Balanitesaegyptiaca callus against Aedesaegyptimosquitoe. BioresourceTechnololgy, 99, 1165-1168.

[44] Khan ME, Abdu KB, Aga T and Lawan ZU. (2008). Chemical Analysis and the Chemotherapeutics of Stem-Bark of Balanitesaegyptiaca. Continental Journal of Applied Science, 3, 95 - 102.

[45] Yadav JP and Panghal M. (2010). Balanitesaegyptiaca (L.) del. A review of its traditional uses, phytochemistry and pharmacological properties. International Journal of Green Pharmacology, 4, 140-146.

[46] Houghton PJ. (2002). The sausage tree (Kigeliaafricana): ethnobotany and recent scientific work. South African Journal of Botany, 68, 14-20.

[47] WHO. (2009). Traditional medicine. 
[48] Grace OM, Light ME, Lindsey KL, Mulholland DA, van Staden J and Jäger AK. (2002). Antibacterial activity and isolation of active compounds from fruit of the traditional African medicinal tree Kigeliaafricana. South African Journal of Botany, 68, 220-222.

[49] Jackson SJ, Houghton PJ, Retsas S and Photiou A. (2000). In VitroCytotoxicity of Norviburtinal and Isopinnatal from Kigeliapinnata Against Cancer Cell Lines. PlantaMedica, 66, 758- 761.

[50] Popenoe W. (1974). Manual of Tropical and Subtropical Fruits. Hafner Press, 432-436.

[51] Tamale E, Jones N and Pswarayi-Riddihough I. (1995). Technologies Related to Participatory Forestry in Tropical and Subtropical Countries. World Bank Publications.

[52] Diallo BO, Joly HI, McKey D, Hosaert-McKey M and Chevallier MH. (2007). Genetic diversity of Tamarindusindica populations: Any clues on the origin from its current distribution. African Journal of Biotechnology, 6, 7.

[53] Morton JF. (1987). Fruits of Warm Climates. Wipf and Stock Publishers, 115-121.

[54] Abubakar MG, Ukwuani AN and Shehu RA. (2008). "Phytochemical Screening and Antibacterial Activity of Tamarindusindica Pulp Extract". Asian Journal of Biochemistry, 3, 134-138.

[55] Michon G, Mary F and Bopmart J. (1986). Multi-Storied agroforestry Garden System in West Sumatra, Indonesia. Agroforestry Systems, 4, 315-338.

[56] Doughari JH. (2006). Antimicrobial Activity of Tamarindusindica. Tropical Journal of Pharmaceutical Research, 5, 597-603.

[57] Khandare AL, Rao GS and Lakshmaiah N. (2002). Effect of tamarind ingestion on fluoride excretion in humans. European Journal of Clinical Nutrition, 56, 82-85.

[58] King AJ, He W, Cuevas JA, Freudenberger RD and Graham IA. (2009). Potential of Jatropha curcas as a source of renewable oil and animal feed: Review paper. Journal of Experimental Botany, 10, 1-9.

[59] Agbogidi OM, Akparobi SO and Eruotor PG. (2013). Health and environmental benefits of Jatropha curcaslinn. Applied Science Reports, 1, 36-39.

[60] Duke JA and Edward SA. (1985). Medicinal plants of China. Michigan Reference Publications. Effects of dietary tamarind on cholesterol metabolism in laying hens. Poultry science, 84, 56-60.

[61] Kumar A, Ashwani CA and Satyawati S. (2008). An evaluation of multipurpose oil seed crop for industrial uses Jatropha curcas L: a review. Industrial Crops and Products, 1-8.

[62] Jongschaap RE, Corre WJ, Bindraban PS and Brandenburg WA. (2007). Claims and facts on Jatropha curcas L. Plant Research International, 7, 20-28.

[63] Kokwaro J0. (2009) .Medicinal plants of East Africa.3rd edition. University Press, Nairobi.

[64] Duke JA. (1994). Biologically active compounds in important species. In: Charalambous, E. ed.. Spices, herbs and edible fungi. Elsevier Science Oxford, 225-250.

[65] Edeoga HO, Okwu DE and Mbaebre BO. (2005). Phytochemical constituents of some Nigerian plants. African Journal of Biotechnology, 44, 685-688.

[66] Agbogidi OM and Eruotor PG. (2012). Morphological Changes due to spent engine oil contamination and its heavy metal components of Jatropha curcas. In: Baby, S. and Sandhu, P.S. eds. Proceedings of the International Conference on Bioscience, Biotechnology and Health Sciences ICBBHs' 2012, organized by Planetary Science Centre Research December 14 and 15, 2012 in Singapore, 88-93.

[67] Duke JA, Bogenschutz-Godwin MJ, DuCellier J and Duke PAK. (2002). Handbook of medicinal herbs. 2nd Edition, Boca Raton, CRC Press.

[68] Aliyu BS. (2006). Some ethnomdicinal plants of the Savannah regions of West Africa: description and phytochemicals. Triumph Publishing Company Ltd, Kano.

[69] Nayak BS and Patel KN. (2010). Pharmacognosis studies of Jatropha curcas leaves. International Journal of Pharmtech Research, 2, 140-143.

[70] Agbogidi OM and Ekeke EA. (2011). Jatropha curcas: Linn an important but neglected plant species in Nigeria. Journal of Biological and Chemical Research, 28, 52-62. 
[71] Okoli RI, Aigbe O, Ohafu-Obode JO and Mensah JK. (2007). Medicinal herbs used for managing some common ailments among Esan people Edo State, Nigeria. Pakistan Journal of Nutrition, 6, 470-490.

[72] Gill LS. (1992). Ethno medicinal use of plants in Nigeria. University of Benin Press, Benin-City.

[73] Rajore S and Batra A. (2003). Jatropha curcas: a plant of immense potential value. Journal of Ecology, Taxonomy and Botany, 27, 36-41.

[74] Leung AY and Foster S. (1996). Encyclopedia of common natural ingredients used in food, drugs and cosmetics, 2nd ed, John Wiley and Sons, New York.

[75] Mahadevan N, Shivali K and Kamboj P. (2009). Hibiscus sabdariffa Linn. An overview. Natural Products Radiance, 8, 77-83.

[76] Chang YC, Huang HP, Hsu JD, Yang SF and Wang CJ. (2005). Hibiscus anthocyanins rich extract induced apoptotic cell death in human promyelocyticleukaemia cells. Toxicological Application of Pharmacology, 205, 201-212.

[77] Odigie IP, Ettarh RR and Adigun SA. (2003). The effect of aqueous extract of petals of Hibiscus sabdariffa (HS) on the established stages of 2-kidney, 1-cliprenovascular hypertension. Journal of Ethnopharmacology, 86, 181-185.

[78] Bokkestijn A and Francis JK. (1986). Khaya senegalensisJuss. Dry-zone mahogany. SO-ITF-SM-5. Rio Piedras, Institute of Tropical Forestry.

[79] Hong TD, Linington S and Elli RH. (1996). Seed storage behaviour: a compendium. Handbooks for Genebanks: No. 4. IPGRI.

[80] vonMaydell HJ. (1986). Trees and shrubs of the Sahel - their characteristics and uses. GTZ 6MBH, Eschborn.

[81] Sahni KC. (1968). Important trees of the northern Sudan. United Nations and FAO.

[82] FAO. (1986). Some medicinal plants of Africa and Latin America. FAO Forestry Paper. 67.

[83] Ajay B, Kothari S, Saxena S and Jain M. (2011). Comparative effect of Neem stick and toothbrush on plaque removal and gingival health A clinical trial. Journal of Advanced Oral Research, 2, 51-56.

[84] YashRoy RC and Gupta PK. (2000). "Neem-seed oil inhibits growth of termite surface-tunnels". Indian Journal of Toxicology, 7, 49-50.

[85] Sidhu OP, Kumar VK and Behl HM. (2003). Variability in Neem (Azadirachtaindica) with Respect to Azadirachtin Content. Journal of Agricultural and Food Chemistry, 51, 910-915.

[86] Ganguli S. (2002). Neem: A therapeutic for all seasons. Current Science, 82, 1304.

[87] Gunjan P, Bhojwani SS and Srivastava AK. (2002). Production of azadirachtin from plant tissue culture: State of the art and future prospects. Biotechnology and Bioprocess Engineering, 7, 185-193.

[88] Bhaskara MV, Pramoda SJ, Jeevikaa MU, Chandana PK and Shetteppa G. (2010). Letters: MR Imaging Findings of Neem Oil Poisoning. American Journal of Neuroradiology, 31, 60-61.

[89] National Academy of Sciences. (1980). Firewood crops; shrubs and tree species for energy production (Vol. I and II). National Academy Press, Washington, D.C., 237.

[90] Ecocrop. (2012). Ecocrop database. FAO

[91] Fagg CW and Mugedo JZA. (2005). Acacia nilotica (L.) Willd. exDelile.. In: Jansen, P.C.M. \&Cardon, D. (Eds). Record from Protabase. PROTA (Plant Resources of Tropical Africa / Ressourcesvégétales de l'Afriquetropicale), Wageningen, Netherlands.

[92] Bargali K and Bargali SS. (2009). Acacia nilotica : a multipurpose leguminous plant. Nature Science, 7, 11-19.

[93] Cook BG, Pengelly BC, Brown SD, Donnelly JL, Eagles DA, Franco MA, Hanson J, Mullen BF, Partridge IJ, Peters M and Schultze-Kraft R. (2005). Tropical forages. CSIRO, DPI and F(Qld), CIAT and ILRI, Brisbane, Australia.

[94] Anokboggo WW. (1992). The role of African traditional medicine in health care delivery alongside modern medicine. In: Botany 2000 East and central African. Edwards, S. and Z. Asfaw (Eds.). Addis Ababa University, Addis Ababa, 25-35.

[95] Cunningham AB. (1993). African medicinal plants: Setting priorities at the interface between conservation and primary health care. People and plants working paper 1. Paris. UNESCO. 
[96] Kokwaro J0. (1991). Conservation of medicinal plants in Kenya. In O. Akerele; V. Heywood; H. Synge eds), Conservation of Medicinal Plants, 315 - 320.

[97] Leach G and Mearns R. (1989). Beyond the fuelwood crisis: People, Land and Trees in Africa. London, Earthscan.

[98] Kgathi DL. (1984). Firewood Trade between Botswana's Rural Kweneng and Urban Gaborone: Employment Creation and Deforestation. Annual journal, Forestry Association of Botswana.

[99] Hedberg I and Hedberg O. (eds.). (1968). Conservation of Vegetation in Africa South of the Sahara. Proceedings of the AETFAT Congress, Uppsala. Acta PhytogeographicaSuecica 54. Uppsala, Almqvist and Wiksells.

[100] Huntley BJ. (1988). Conserving and monitoring biotic diversity: some African examples. In Wilson, E. O. (ed.) Biodiversity, 144-147.

[101] Richter M. (2004).Traditional healing and human rights in South Africa.

[102] WHO. (2008). Fact sheetNo, 134.

[103] Schippmann U, Leaman D and Cunningham A. (2002). Impact of cultivation and gathering of medicinal plants on biodiversity: Global trends and issues. FAO, Rome, Italy.

[104] Hamilton A, Dürbeck K and Lawrence A. (2006). Towards a sustainable herbal harvest. Plant Talk , 43, 32-35.

[105] Gesler WM. (1984). Healthcare in developing countries. Resource Publications in Geography, Washington DC.

[106] Hedberg I, Hedberg O, Madati PJ, Mshigeni KE, Mshiu EN and Samuelson G. (1982). Inventory of plants used in traditional medicine in Tanzania. 1. Plants of the families Acanthaceae - Cucurbitaceae. Journal ofEthnopharmacology, 6, 29 - 60.

[107] Anyinam C. (1987). Availability, accessibility, acceptability and adaptability: four attributes of African ethnomedicine. Society of Science and Medicine, 25, 803 - 811.

[108] Scudder T and Connelly T. (1985). Management Systems for Riverine Fisheries. IDA report.

[109] Akerele 0. (1987). The best of both worlds: bringing traditional medicine up to date. Society of Science and Medicine, 24, 177 - 181.

[110] Good CM. (1987). Ethnomedical systems in Africa: patterns of traditional medicine in rural and urban Kenya. Kenya. The Guildford Press.

[111] Last M and Chavunduka GL. (1986). The Professionalization of African Medicine. Manchester, Manchester University Press.

[112] World Bank. (2004). Sustaining Forests: A Development Perspective. World Bank Publications, Washington, D.C, US.

[113] Husain A. (1991). Economic aspects of exploitation of medicinal plants. In O. Akerele; V. Heywood; H. Synge. Conservation of Medicinal Plants, 125 - 140.

[114] Leach G and Mearns R. (1989). Beyond the fuelwood crisis: People, Land and Trees in Africa. London, Earthscan.

[115] Eberhard AA. (1986). Energy Consumption Patterns in Underdeveloped Areas in Southern Africa. Report 94, Energy Research Institute. Cape Town, South Africa. University of Cape Town.

[116] Farnsworth NR. (1988). Screening plants for new medicines. In Wilson, E.O. (ed.) Biodiversity, 83 - 97.

[117] Lobos L, Synge H and Zantovska J. (1986). Plants in Danger: What Do We Know? Gland, Switzerland. IUCN.

[118] Gelfand M, Mavi S, Drummond RB and Ndemera B. (1985). The Traditional Medical Practitioner in Zimbabwe. Harare, Mambo Press.

\section{How to cite this article}

Joseph DWL, Kenneth Lado LS, Clara Stephen GL, Jada PY, James Augustino MU, Sampson AB, Yatta Samuel LN, Massimo KM, Thomas FL and Awad HK. (2020). Diversity and distribution of medicinal plants in the Republic of South Sudan. World Journal of Advanced Research and Reviews, 7(1), 18-31. 